Articles 


\title{
Entrenched Derogations from the European Convention on Human Rights and the Emergence of Non-Judicial Supervision of Derogations
}

\author{
Kushtrim Istrefi* and Stefan Salomon ${ }^{* *}$
}

\section{Introduction}

In time of war, law is silent, argued Cicero. This ancient rule has not been fully set aside even with the evolution of international human rights law. Article 15 of the European Convention on Human Rights (ECHR or the Convention) recognizes that in time of war or other public emergencies part of the Convention, namely, the so-called derogable rights, can be muted in a given territory. ${ }^{1}$

The derogation clause was for long seen by scholars as problematic. Some pointed to the underlying paradox: States are permitted to derogate from human rights in situations of emergencies, precisely the time when many grave human rights violations will occur. ${ }^{2}$ Others noted the weak supervisory role of the European Court of Human Rights (ECtHR or the Strasbourg Court) in derogation cases. ${ }^{3}$ Scholars have also been preoccupied with the long

* Kushtrim Istrefi is Assistant Professor of Public International Law and Human Rights at Utrecht University.

** Stefan Salomon is lecturer at the Institute of International Law and International Relations at the University of Graz.

1 Art 15(2) European Convention for the Protection of Human Rights and Fundamental Freedoms, 3 September 1953, 213 UNTS 222.

2 Evan J Criddle and Evan Fox-Decent, 'Human Rights, Emergencies, and the Rule of Law' (2012) 34 Human Rights Quarterly 39, 49.

3 Joan F Hartman, 'Derogation from Human Rights Treaties in Public Emergencies - A Critique of Implementation by the European Commission and Court of Human Rights and the Human Rights Committee of the United Nations' (1981) 22 Harvard International Law Journal 50; Jan-Peter Loof, 'Crisis Situations, Counter Terrorism and Derogations from the European Convention of Human 
duration of derogations in the context of, for example, terrorism. Scholars and institutions have argued that derogations from the ECHR are justified only if they are temporary and have used terms such as 'permanent' or 'entrenched' derogation to highlight problematic instances of derogation in times of enduring wars or emergencies. ${ }^{4}$ This contribution aims to discuss this aspect of derogations, namely the conundrum of temporariness in derogation regimes.

In the following, we examine two theoretical assumptions. First, the assumption that derogation is temporary, in the sense that it has to be measurably short. Second, the assumption that wartime and emergency times are temporary. Section III turns to the origin of these assumptions and whether they find support in the language of Article 15 ECHR and the case law of the Strasbourg Court. Section IV zooms out, explores broader problems of derogation regimes, whether of long or short duration, and identifies measures that can enhance effective international supervision of derogations. To that end, section V provides policy recommendations on how the Strasbourg Court and some non-judicial institutions should deal with complex issues arising from derogation regimes.

\section{Assumptions on Derogations}

\section{A. The Assumption of the Temporary Nature of Derogation}

The duration of derogation measures has for long preoccupied institutions and scholars working on the issue of derogation from human rights treaties. Frequently it has been suggested that derogations can be justified only if they are of short duration. Time, therefore, has been employed as an element to assess derogation instances.

Rights: A Threat Analysis' in Antoine Buyse (ed) Margins of Conflict: The ECHR and Transitions to and from Armed Conflict (2010) 55.

4 See Oren Gross, “"Once More unto the Breach”: The Systemic Failure of Applying the European Convention on Human Rights to Entrenched Emergencies' (1998) 23 Yale Journal of International Law 438; UN Human Rights Committee, General Comment 5/13 (1981) UN Doc A/36/40; see UN Human Rights Committee, CCPR General Comment No 29: Article 4: Derogations during a State of Emergency, 31 August 2001, UN Doc CCPR/C/21/Rev.1/Add.11, para 2; Human Rights Council, Report of the Special Rapporteur on the promotion and protection of human rights and fundamental freedoms while countering terrorism on the human rights challenge of states of emergency in the context of countering terrorism, 27 February 2018, UN Doc A/HRC/37/52. 
In 1981 and again in 2001, the UN Human Rights Committee held that measures derogating from the International Covenant on Civil and Political Rights (ICCPR) must be of temporary nature. ${ }^{5}$ Scholars too have argued that derogation regimes under the ECHR and other human rights treaties rest on, among others, the component of temporariness. ${ }^{6}$ Two decades ago, Gross observed that ' $[\mathrm{t}]$ he derogation system adopts a vision of spasms of $[\ldots]$ sporadic events, $[\ldots]$ - that last for a relatively brief period of time'. Based on this understanding, Gross criticized the ECtHR for ignoring the nature and effects of entrenched emergencies in cases concerning the UK's prolonged derogation with respect to Northern Ireland and Turkey's prolonged derogation with respect to its southeast region. ${ }^{8}$

The debate on temporariness of derogation re-emerged in the wake of recent derogations from ECHR by, among others, France and Turkey. In a report from February 2018, the UN Special Rapporteur on the promotion and protection of human rights and fundamental freedoms while countering terrorism (hereinafter the UN Rapporteur) discussed the temporary character of derogations. She concluded that 'all measures derogating from the provisions of the International Covenant on Civil and Political Rights (and/or regional human rights treaties) must be of an exceptional and temporary nature'. ${ }^{9}$ This view was more recently reflected in the report on derogations from the ECHR prepared by the Council of Europe Rapporteur on State of Emergency. The report, endorsed by the Parliamentary Assembly of the Council of Europe (PACE), asserts that 'derogation must be limited in duration' ${ }^{10}{ }^{10}$ In relation to current derogations from the ECHR, the report discusses the appropriateness of entrenched emergencies in France and Turkey. In this regard, the report states that the duration of derogation by France has 'become questionably

5 General Comment 5/13, supra note 4; General Comment No 29, supra note 4, at para 2.

6 Gross, supra note 4, at 445. At the same time, Gross recognizes that emergencies are oftentimes of long duration and thus the assumption of temporariness does not reflect the realities of emergencies.

7 Gross, supra note 4, at 453.

8 Gross, supra note 4, at 500.

9 UN Doc A/HRC/37/52 'States of emergencies and terrorism', supra note 4, at para 10.

10 Parliamentary Assembly of the Council of Europe, Resolution 2209 (2018): State of emergency - proportionality issues concerning derogations under Article 15 of the European Convention on Human Rights, 24 April 2018, para 4. 
long'. ${ }^{11}$ Interestingly, the report does not clarify whether the derogation has lasted longer than the threat justifying the derogation measures. It would have been useful if the report explained the grounds on which it questions the duration of derogation by France. In the case of Turkey, the report is even more straightforward on this matter. The report finds that 'the duration of the state of emergency has exceeded what is strictly required'. ${ }^{12}$ Here too, the report does not suggest that the security situation in Turkey has improved and thus the derogation can no longer be justified. To the contrary, the report recalls that since the coup attempt, Turkey has repeatedly suffered from terrorist attacks. ${ }^{13}$

The foregoing suggests that prolonged derogations from the ECHR and other human rights instruments have oftentimes been criticised based on the assumption that derogations must be temporary. Furthermore, the manner in which the element of temporariness has been used suggests that derogations should not only be short, but also measurably short. This creates, at times, an impression that a derogation extending over a longer period of time is by default unjustified or illegal.

\section{B. The Assumption of the Temporary Nature of Wartime and Emergency Time}

The observation made above on the temporariness of derogation appears to be grounded on the belief that peace is the normal state and peacetime is hence of permanent nature, while emergency is an exceptional state and emergency time should hence be measurably short; . Mary Dudziak suggests, in an excellent study on the temporality of war, that this belief derives from the assumption that emergency time or "wartime is always followed by peacetime, and therefore that an essential aspect of [emergency time or] wartime is that it is temporary' ${ }^{14}$ She argues, however, that the assumptions about the temporality of war "clash with our experience of twenty-firstcentury war, revealing that confusion about time obscures our understanding of contemporary war' ${ }^{15}$ Illustrating the enduring nature of terrorism and

\footnotetext{
$11 \quad$ Ibid., at para 13.

12 Ibid., at para 16.2 .

13 Ibid., at para 15.

14 Mary Dudziak, War Time (2012) 4.

15 Ibid.
} 
other contemporary wars and emergencies Dudziak asks: 'how can we end a wartime when war doesn't come to an end? ${ }^{16}$

This question is highly relevant in the context of derogation practices, old and new. If terrorism, as an enduring condition, may justify derogations from human rights instruments, then we may ask: 'How can we end derogation time when emergencies do not come to an end?'

It is in this context that we may recall the French notification of derogation from the ECHR to the Council of Europe, which stated that the "terrorist threat in France is of lasting nature' ${ }^{17}$ The derogation notice seemed to suggest that France might derogate from the ECHR until all the terrorist threats cease to exist. Similar arguments on derogations were used long before the emergence of 'modern terrorism'. Already in the 1950s, the British Governor of Cyprus Sir John Harding made the following comments regarding the duration of derogation from the ECHR: 'until the remaining terrorists are killed, captured or leave the island, and until it becomes certain that there exists no further danger of a renewal of terrorism, there can be no question of ending the state of emergency. ${ }^{18}$

These discussions on the assumption of temporariness of derogations and emergency times have for long been explored in a theoretical realm. The next part will look at what the law and jurisprudence under the ECHR say about the assumptions of a time element in the assessment of instances of derogation.

\section{Temporariness of Derogations in ECHR Law and Jurisprudence}

The preceding arguments illustrate the common assumption that derogations are justified if they are measurably short in time. However, the wording of Article 15 ECHR does not support this assumption. Article 15 ECHR permits states to derogate from the obligations of the Convention in 'time of war or other public emergencies' and sets forth the procedural obligation to inform the Secretary General of the Council of Europe without any delay of the

\footnotetext{
16 Ibid.

17 Resolution 2209 (2018), supra note 10, at para 10.

18 Greecev UK, ECommHR, Application No 176/56, Decision of 26 September 1958, para 122.
} 
derogatory measures..$^{19} \mathrm{~A}$ time of war or public emergency is not restrained to a specifically defined duration: it may be of long or short durée.

States generally specify the duration of the derogation in their derogation notices, but that is not an obligation that derives from Article 15 ECHR. Moreover, if states limit the duration of the derogation in the first place and subsequently extend the derogatory measures in time, Article 15 ECHR is silent on any temporal limitation to such extensions. This is confirmed by the case law of the ECtHR.

In its Ireland case law, for instance, the Court rejected the argument that derogations were invalid for the reason that the underlying situation of emergency is of quasi-permanent nature. In Brannigan and McBride $v U K$, the applicants argued precisely that: that the derogation was invalid as it applied to a situation of emergency that was of 'quasi-permanent nature' ${ }^{20}$ Relying on its wide margin of appreciation doctrine, the Court held that the national authorities were in principle in a better position to judge whether the 'pressing needs of the moment' constituted an emergency, as well as on the nature and scope of derogatory measures necessary to tackle the emergency. ${ }^{21}$ Thus, the Court did not accept the argument that a quasi-permanent emergency could invalidate derogations in principle. Rather, derogations had to be considered in the light of the circumstances which had existed at the time they had been made. Similarly, in Marshall v UK, the Court did not accept the applicant's argument that derogatory measures were excessive in time. The applicant argued that derogatory measures introduced by UK government in 1988, and maintained after the Irish Republican Army (IRA) announced a unilateral ceasefire in 1994, had been excessive in time and that the imposition of a permanent state of emergency should not be permitted under the Convention. ${ }^{22}$ Instead of engaging in an analysis of the derogation period that had exceeded 10 years, the Court limited its analysis to acts that had occurred in the immediate temporal proximity of the applicant's arrest and concluded that the emergency had still been present. ${ }^{23}$

The Court's subsequent case law on terrorism illustrates the absence of temporal requirements for derogation more clearly. In $A$ and Others $v U K$, the

19 See Art 15, paras 1 and 3 ECHR.

20 Brannigan and McBride v UK, ECtHR, Application No 14553/89, Judgment of 25 May 1993), para 41.

21 Ibid., at para 43.

22 Marshall v UK, ECtHR, Application No 41571/98, Decision of 10 July 2001, pp 7-9.

$23 \quad$ Ibid., at $\mathrm{p} 12$. 
Court rejected the applicants' argument that no public emergency could have existed as the emergency had not been temporary. The Court rather explicitly disagreed with the Human Rights Committee that public emergency had to be of 'temporary nature'. ${ }^{24}$ Instead, the Court held that

While the United Nations Human Rights Committee has observed that measures derogating from the provisions of the International Covenant on Civil and Political Rights must be of 'an exceptional and temporary nature' $[. .$.$] the Court's case-law has never, to date, explicitly incorporated$ the requirement that the emergency be temporary, although the question of the proportionality of the response may be linked to the duration of the emergency. Indeed, the cases cited above, relating to the security situation in Northern Ireland, demonstrate that it is possible for a 'public emergency' within the meaning of Article 15 to continue for many years. The Court does not consider that derogating measures put in place in the immediate aftermath of the al-Qaeda attacks in the United States of America, and reviewed on an annual basis by Parliament, can be said to be invalid on the ground that they were not 'temporary'. ${ }^{25}$

Two different points can be inferred from the Court's statement above. First, the Court explicitly rejects the argument that a situation of emergency invariably is of a temporary nature. Second, the Court derives from the fact that Article 15 does not require a temporal limitation of derogation that derogatory measures are not invalid simply because they are not temporary in nature. This means that it is not mandatory to include a specific duration of the derogatory measures into the derogation notice and, even when states include temporal limitations, no specific limitation exists to the extension of such derogatory measures. Hence, there are no requirements that derive from the ECHR to concretely limit derogatory measures in time. Derogations in the Ireland case law were based on situations of emergency that had lasted for more than a decade and, when the complaint was lodged before the ECtHR in $A$ and Others, the emergency had lasted already for more than four years. In its assessment of whether the situation in $A$ and Others constituted an emergency, the Court, in addition to invoking the wide margin of appreciation afforded to states on the question of the existence of a state of emergency, seemed to rely on a momentous assessment of threats rather than a more comprehensive analysis of the entire period of derogation. Thus, the Court

24 General Comment No 29, supra note 4, at para 4.

25 A and Others $v$ UK, ECtHR, Application No 3455/05, Judgment of 19 February 2009, para 178. 
appeared to acknowledge 'an inherently fluid and changing situation' that may be temporally extended. ${ }^{26}$

However, while the Court stated that the Convention does not include a requirement for situations of emergency to be of temporary nature, this does not mean that temporality of an emergency is entirely absent from the Court's analysis. As the above-cited passage in $A$ and Others illustrates, the duration of a conflict may be significant in assessing the proportionality of derogatory measures aimed at addressing such a situation. ${ }^{27}$ It is, however, not clear from the case law of the Court how the duration of threat is to be balanced in relation to individual rights and what precise role, if any, temporality plays in the judges' assessment of derogations.

The Ireland case law and, in particular, the Court's subsequent jurisprudence on derogation in the context of terrorism reflect the wording of Article 15 ECHR and the absence of concrete time limitations of derogatory measures. Where, then, does this belief in the temporality of emergencies and derogations come from?

\section{Investigating the Origin of Temporariness}

\section{A. The Two Vernaculars of Emergency: Constitutional Law and International Law}

The belief about temporality of derogations under the ECHR could be based on the confusion of two different legal vernaculars on emergencies. On a conceptual level, international human rights law and constitutional law share the same legal concepts and 'typical' arguments in regard to situations of emergency. However, the way legal concepts and arguments are expressed in regard to a particular positive rule on emergencies, either in a specific human rights regime (e.g. ECHR, ICCPR) or in a specific domestic constitution, will be different. ${ }^{28}$ Hence, the two vernaculars are: (i) state of emergency as a

26 Ireland v UK, ECtHR, Application No 5310/71, Judgment of 18 January 1978), p 84.

27 David Dyzenhaus, 'States of Emergency' in Michel Rosenfeld and András Sajó (eds), The Oxford Handbook of Comparative Constitutional Law (2012) 456.

28 It could be compared to a language that has a conceptual framework and vocabulary, but entails different vernacular languages, or vernaculars, that determine how exactly a grammatical rule is applied (or not) and a word pronounced. See 
constitutional vernacular; and (ii) situations of emergency as an international human rights law vernacular. While both regimes are intertwined, they are not synonymous to each other. This means that the notions of time and temporariness in relation to a state of emergency (in the constitutional vernacular) and derogation (in the international human rights law vernacular) are guided by different legal sources, have different meanings, and also different legal effects. Strict temporal limitations in constitutional law do not derive a priori from the assumption that the duration of emergencies is limited in time but are rather rooted in concerns on maintaining institutional power balances and avoiding an institutional power shift to the executive branch. However, treatises on derogation under Article 15 ECHR appear to mesh these two different legal vernaculars. In the absence of time restraints in the wording of Article 15 ECHR, they often add references to and discussions of constitutional law and theory on the state of exception. ${ }^{29}$

The main difference between the international human rights law vernacular and the constitutional law vernacular on the state of emergency relates to institutional aspects addressed by the latter. A declaration of a state of emergencies under constitutional law involves a broader background of institutional checks and balances. For instance, the executive often gains additional competences to enact legal acts for which it would otherwise need parliamentary approval and is not subject to judicial scrutiny to the extent it is under non-emergency time. A rough typology of emergency provisions in constitutions would include the following: (i) rules that transfer law-making competences from the legislative to the executive; (ii) rules that render procedures of law-making and of law-enforcement more flexible; and (iii) rules that pertain to substantive changes to, or limitations of, norms. ${ }^{30}$ This rough typology of emergency provisions in constitutions illustrates that constitutional law is largely concerned with institutional power shifts between the three branches of the state. Strict temporal limitations on states of emergency in constitutional law primarily aim to maintain an institutional power balance and to avoid the concentration of power in the executive branch. That does not

Duncan Kennedy, 'Three Globalizations of Law and Legal Thought: 1850-2000' in David Trubek and Alvaro Santos (eds), The New Law and Economic Development (2006) 23.

29 Andrej Zwitter, 'Rechtstheoretische Erläuterungen zur Begrifflichkeit und Theorie des Staatsnotstandsrechts' in Andrej Zwitter (ed), Notstand und Recht (2012) 34-41; see also Dyzenhaus, supra note 27.

30 For such an early typology, see Friedrich Koja, 'Staatsnotstand als Rechtsbegriff' (1975) 8 Österreichische Juristenzeitung 209 
necessarily imply that situations of emergency have to be short. In contrast, derogations under Article 15 ECHR largely concern substantive restrictions of human rights norms, which would otherwise be unlawful under 'normal' circumstances in which states can limit rights under the ECHR.

Unlike Article 15 ECHR and the jurisprudence of the Court, most constitutions provide for strict time limits on the duration of a state of emergency. Approximately $90 \%$ of the constitutions enshrine explicit provisions on situations of emergency, ${ }^{31}$ and the overwhelming majority of these provisions include specific time restraints and limitations. For instance, the Constitution of Brazil provides that a state of siege or a state of defense must be determined temporarily, and strictly limits both to a maximum of thirty days..$^{32}$ The Constitution of India provides that the declaration of a state of emergency ceases to apply after one month from the date it was issued, unless both Houses of Parliament approve a resolution extending the state of emergency for a maximum further period of six months. ${ }^{33}$ The South African Constitution strictly limits the declaration of a state of emergency and any legislation due to the state of emergency to twenty-one days. Subsequent extensions of the state of emergency have to be approved by at least $60 \%$ of the members of the National Assembly (except for the first extension that can be adopted with absolute majority) and are limited to three months. ${ }^{34}$

\section{B. The Origins of Emergency Law in Roman Legal Thought}

The constitutional design of emergency provisions has its origins in Roman constitutional thought. Although, broadly speaking, constitutional emergency provisions in common law emerged from martial law and in civil law from the emergency provision in the Weimar Constitution, ${ }^{35}$ in both traditions the jurisprudential justification of suspensions of fundamental rights and liberties

31 Christian Bjornskov and Stefan Voigt, 'The Architecture of Emergency Constitutions' (2018) 16 International Journal of Constitutional Law 101, 101. Gross and Aoláin enumerate the constitutions of Belgium, the US and Japan that are 'almost entirely devoid', but not entirely devoid, of emergency powers, see Oren Gross and Fionnuala Ní Aoláin, Law in Times of Crisis (2006) at 37.

32 See Art 136 (declaration of state of defense) and Art 137 (state of siege) Constitution of the Federative Republic of Brazil of 1988.

33 Art 352 Constitution of India of 1949.

34 Section 37(2) Constitution of the Republic of South Africa of 1996.

35 Dyzenhaus, supra note 27 , at 446 . This typology is merely a very rough, superficial distinction. 
is rooted in Roman law. ${ }^{36}$ Roman constitutional thought vested power in the office of dictatorship in times of emergency that resulted either from external aggression or internal disturbances. ${ }^{37}$ The dictator, an extraordinary magistrate, was appointed by any of the consuls after a decision of the senate had found that an emergency situation required a dictator.

Roman law set forth detailed procedural and substantive rules for the office of dictatorship. For instance, the decisions of the dictator could not be vetoed; there was no right of appeal to popular assemblies against the decisions of the dictator; the dictator enjoyed immunity for the actions taken in office after he had laid down his office; he enjoyed comprehensive jurisdiction in criminal law cases; and, within constitutional limits, had jurisdiction over capital punishment. In short, the dictator was largely freed from constitutional checks that restricted the power of ordinary officials.

Most importantly, however, the office of dictatorship was temporally limited. Roman law set forth two temporal restraints. An absolute limitation restricted the office of the dictator to a maximum of six months. The relative limitation implied that the office of a dictator could not exceed the term of office of the consul who had appointed him..$^{38}$ Marc de Wilde points out that these temporal limitations were rarely violated. In the three hundred years between the first recorded appointment of a dictator, $\mathrm{T}$ Larcius Flavus (501 BC) and the last dictator, C Servilius (202 BC), of the ninety-four dictators appointed in that period, only six seemed to have overextended their term. The six months limit however contained a certain degree of flexibility. Informal rules prescribed that if the task for which the dictator was appointed was finished prior to the expiration of the six months term, it was assumed that he would relinquish his powers and office; equally, dictators were sometimes permitted to exceed the six months term depending on the nature of the task that needed to be fulfilled. De Wilde argues that in addition

36 Blackstone, Commentaries on the Laws of England, Book 1, Chapter 7, <lonang. com/library/reference/blackstone-commentaries-law-england/bla-107/> accessed 26 April 2019; Halsbury's Laws of England Vol 8 (1983) 625, para 982.

37 For concise accounts on the Roman law on dictatorship, see Marc de Wilde, 'The Dictator's Trust: Regulating and Constraining Emergency Powers in the Roman Republic' (2012) 33 History of Political Thought 555; Benjamin Straumann, 'Constitutional Thought in the Late Roman Republic' (2011) 32 History of Political Thought 280 (arguing for the existence of Roman constitutional thought on the basis of the existence of emergency provisions in Roman law); for an early account, see Robert Bronner, 'Emergency Government in Rome and Athens' (1922) 18 The Classical Journal 144.

38 de Wilde, supra note 37, at 555, 560. 
to strict formal rules, informal rules, such as fides (trust), played a significant part in preventing dictatorial abuse of power by unilaterally exceeding the dictatorship term. ${ }^{39}$

Roman constitutional thought on the importance of temporal limitations of states of emergency was crucial for subsequent political and constitutional theory ${ }^{40}$ Indeed, different models of constitutional accommodation of emergency provisions in the latter half of the $19^{\text {th }}$ century and the outset of the $20^{\text {th }}$ century included the idea (if not at all times in the form of a legal requirement) that situations of emergency are restrained in time and any revocation or suspension of fundamental rights is thus only temporary. ${ }^{41}$

Hence, for the constitutional law vernacular the importance of Roman constitutional thinking lies in two aspects. First, most constitutions set out strict temporal restraints for situations of emergency, thus taking up Roman constitutional thought on the significance of temporal restraints on the office of dictatorship in order to avoid abuse of power. Second, in Roman constitutional thought, the need to prevent abuse of power by the dictator was primarily due to the desire to avoid power shifts that could fundamentally alter the republic's normal institutional arrangements and structures. This idea is reflected in the constitutional law vernacular

39 de Wilde, supra note 37, at 561-562, 571.

40 Machiavelli for instance stated: 'For when free authority is given for a long time (calling a long time a year or more) it is always dangerous and will produce effects either good or bad according as those upon whom it is conferred are good or bad [...]. And because of this, it ought to be noted that when (we said) an authority given by free suffrage never harmed any Republic, it presupposed that a People is never led to give it except with limited powers and for limited times.' (Niccolo Machiavelli, Discourses on Livy (transl. by Harvey Mansfield and Nathan Tarcov, 1996) 76). See also Gross and Aoláin, supra note 31, at chapter 1.

41 Art 48(2) Verfassung des Deutschen Reiches of 1919 (Weimar Constitution); Rainer Grote, 'Regulating the State of Emergency - The German Example' (2003) 33 Israel Yearbook on Human Rights 151; early French law on the state of siege of 1849 is an exception in that it does not provide temporal limitations. The Law of 1878 however, subsequently introduced temporal limitation (see Gross and Aoláin, supra note 31, at 26-30). 


\section{Strengthening the European Supervision of Emergency Measures}

\section{A. Judicial Activism}

The absence of time restraints on the duration of derogations in the wording of the ECHR does not mean that the concerns of constitutional thought about institutional balance in states of emergency are unjustified. However, it also does not imply that constitutional provisions necessarily provide sufficient safeguards. Quite to the contrary, the Strasbourg Court can and should seek ways to tackle problematic derogation practices and to take a more proactive role on derogations. Indeed, the Convention leaves sufficient room for the Court to be more proactive in this regard. But the question remains as to how should it discharge this task.

Under the current policy of the Court on the examination of incoming cases, applications relating to derogatory measures do not enjoy priority. Derogation cases are not classified as 'urgent cases' and thus it may take years until the Court decides on such cases. The category of 'urgent cases' concerns substantive issues that relate to risks to life or health or deprivations of liberty. Cases that may impact the effectiveness of the Convention system or that are of general interest are one notch below on the priority ladder. ${ }^{42}$ Arguably, recent derogations all include limitations of the right to liberty, but they do not seem to enjoy sufficient priority to be included within the cluster of 'urgent cases'. Moreover, a large extent of derogatory measures concern limitations of freedom of assembly and speech (Turkey, France) ${ }^{43}$ limitations of freedom of movement of persons suspected of terrorist activities (France),

42 The Court's Priority Policy <www.echr.coe.int/Documents/Priority_policy_ENG. pdf $>$ accessed 26 April 2019.

43 France adopted on 30 October 2017 a new law on the reinforcement of 'domestic security and the fight against terrorism' and subsequently ended the state of emergency. See the speech of Emmanuel Macron before the ECtHR on 1 November 2017, Transcription du discours du Président de la République à la Cour européenne des Droits de l'Homme, Elysée Palace, <elysee.fr/declarations/article/ transcription-du-discours-du-president-de-la-republique-a-la-cour-europeennedes-droits-de-l-homme/> accessed 26 April 2019. Hence, the derogations referred to above refer to the derogatory measures of France put in place by the Decree of the President of the Republic, No 2015-1475, 14 November 2015 and its subsequent extensions. 
and massive purges from the public sector (Turkey). ${ }^{44}$ As these measures are coupled with limitations of judicial review, it would be odd to argue that an individual deprivation of liberty is more urgent than these measures that might jeopardize the social existence of thousands of people. Under the current priority scheme of the Court, such cases would not be considered 'urgent' and thus would not be dealt with as priority cases. However, absent any concrete time restraints in the Convention, an expeditious examination of cases by the Court is necessary for a number of reasons.

First, as mentioned, derogatory measures adopted during situations of emergency shift the institutional power balance to the executive. Derogations in situations of emergency transfer competences and control to the executive so that it can exercise 'real' power. This issue relates, however, to a more profound and important aspect of power. A shift of competences is not merely an empirical fact, but is simultaneously and (perhaps) primarily a justification for the argument that a 'strong hand' is needed..$^{45}$ Given that, as a matter of fact, it is often the government that has access to the relevant empirical information that would allow an assessment of whether measures are effective or to determine what is the 'real' extent of a threat, derogatory measures are a formidable means of convincing people of the need of the strong hand of the executive. ${ }^{46}$ Proclamations of a state of emergency, and the attendant derogation of the ECHR, may thus serve as a smokescreen to reassure the populace that 'something is being done' against the potential threat. ${ }^{47}$

Second, when examining an application concerning a possible human rights violation that is directly linked to a derogation, the Court should explicitly address systematic issues that involve the effective functioning of

44 The Turkish government formally notified the Secretary General of the Council of Europe on 8 August 2018 of the end of its derogations from the ECHR. Hence, the derogatory measures referred to above, refer to the derogations notified on 22 July 2016 by the Turkish government to the Council of Europe and the subsequent extensions.

45 On a conception of justificatory power see Rainer Forst, 'Noumenal Power' (2015) 23 Journal of Political Philosophy 111.

46 As the concurring judges in Tymoshenko v Ukraine aptly pointed out: 'Generally, knowledge about what the Court calls a "hidden agenda" is within the sphere of the authorities and is thus not accessible to an applicant.' (Tymoshenko v Ukraine, ECtHR, Application No 49872/11, Judgment of 30 April 2013, Joint Concurring Opinion of Judges Jungwiert, Nussberger and Potocki).

47 See Luca Pasquet, 'The French State of Emergency: From Crime-Repression to the Protection of Public Order' (2019) 22 ARIEL 67. 
the Convention system. This can be effectively achieved only if the cases are adjudicated while the derogatory measures are in place.

Third, the active engagement by the Court into such an examination might serve as a signpost to a state pro futuro and might at least limit a backsliding of protection standards which may occur through the transformation of 'temporary' emergency provisions into 'permanent' law.

The Convention already offers the necessary legal basis for such a proactive engagement by the Court. Article 18 ECHR provides that restrictions 'shall not be applied for any purpose other than those for which they have been prescribed' ${ }^{48}$ Derogations under Article 15 ECHR may at times be considered 'restrictions' under Article 18 ECHR. ${ }^{49}$ In relation to Article 18 ECHR, the Court held that limitations ought not to be 'effected for ulterior purpose'. ${ }^{50}$ As it is the government that generally possesses the relevant information on whether a situation of emergency continues to exist and hence a derogation is still needed, the limitation not to employ restrictions for 'ulterior purposes' implies that the government must act in good faith when adopting derogatory measures. Indeed, this has been pointed out by the Courtin Ilgar Mammadov $v$ Azerbaijan when it stated that

the whole structure of the Convention rests on the general assumption that public authorities in the member States act in good faith. Indeed, any public policy or individual measure may have a 'hidden agenda', and the presumption of good faith is rebuttable. ${ }^{51}$

As government agendas change over time, derogatory measures might indeed serve as a convenient vehicle to pursue other interests, such as limiting parliamentary control or preparing the grounds for authoritarian rule. ${ }^{52}$ Temporality then might be a particularly relevant indicator in the assessment of whether a government pursues a 'hidden agenda' by way of derogation measures

48 Art 18 ECHR.

49 William Schabas, The European Convention on Human Rights A Commentary (2015) 625.

50 Ashingdane v UK, ECtHR, Application No 8225/78, Judgment of 28 May 1985, para 48.

51 Ilgar Mammadov v Azerbaijan, ECtHR, Application No 15172/13, Judgment of 22 May 2014, para 137.

52 See Kerem Altıparmak and Senem Gürol, 'Turkey's Derogation of Human Rights under the State of Emergency: Examining its Legitimacy and Proportionality' (2019) 22 ARIEL 101. 
that initially may have been adopted in good faith. In the interpretation of Article $18 \mathrm{ECHR}$, 'the direct link between human rights protection and democracy must be taken into account. ${ }^{53}$ In $A$ and Others, where the Court held that derogation measures are not invalid solely on grounds of not being temporary, the Court appears to have followed that line when it added that the derogatory measures are 'reviewed on an annual basis by Parliament' ${ }^{54}$

Although Article 18 ECHR may provide a legal basis for the Court to adopt a more proactive approach, one should be cautious to put too much faith into the balance of institutional power, democratic oversight (which might occur in closed committees), and a rigorous protection of human rights. After all, widespread and systematic violations of human rights (e.g. the secret rendition programme, systematic use of torture in Guantànamo, and secret prisons) have occurred in solid, functioning democracies.

\section{B. The New Layer of Non-Judicial Supervision of Derogations: A Proactive Role of the Secretary General of the Council of Europe}

Although a more proactive role of the Court no doubt is needed, no form of judicial activism alone can resolve the complexity of unfit, unjustified, or abusive derogations, whether of long or short duration. At least three arguments support this view. First, as stated above, rulings focus on individual complaints, and therefore the Court cannot tackle all issues of the respective derogation regime but only those directly connected to the facts of the pending case. Second, even if applications in relation to derogations are considered as priority cases, the Court may nevertheless have other equally important cases on the docket and might thus not be able to provide timely review of derogation measures. For instance, a case is still pending before the Court against Armenia concerning a derogation from the Convention that allowed the government to crush peaceful anti-government protests in Yerevan and resulted in the death of a protester in 2008. ${ }^{55}$ Third, if there are no (admissible) complaints before the ECtHR in relation to a derogation practice, the Court

53 Tymoshenko v Ukraine, supra note 46, Joint Concurring Opinion of Judges Jungwiert, Nussberger and Potocki.

54 A and Others $v$ UK, supra note 15, at para 178.

55 'Armenia's Parliament to discuss deadly 2008 crackdown' OC Media (1 March 2018) < oc-media.org/armenias-parliament-to-discuss-deadly-2008-crackdown/> accessed 26 April 2019. 
simply cannot deliver a judgment on it. For example, the Court has never had an opportunity to issue judgments against Georgia concerning the 2007 derogation measures, which led to more than 500 injured persons for partaking in peaceful protests against the government. ${ }^{56}$

Joan F Hartman argues that the lack of an automatic review process by the ECHR signifies that the Court will 'experience delays in securing essential information about an emergency or, even more seriously, a total inability to take cognizance of derogation situations which are not made the subject of a state-to-state or individual application'. ${ }^{57}$

These considerations suggest that international courts, including the ECtHR, have some inherent limitations to tackle the magnitude of the problems associated with derogations, including the ones related to their duration..$^{58}$ Hence, other non-judicial supervisory institutions need to step in to reduce negative effects that might derive from enduring derogations.

For a long time, the Venice Commission of the Council of Europe was considered one of the scarce non-judicial institutions able and willing to deal with derogation practices. ${ }^{59}$ More recently, the Council of Europe Rapporteur on State of Emergency proposed that another body of the CoE, namely the Secretary General, should take an essential role in engaging with complex issues of derogations. ${ }^{60}$ This proposal, endorsed by PACE in Resolution 2209

56 'Georgia: After crackdown, President calls early elections' RadioFreeEurope (8 November 2008) <rferl.org/a/1079100.html> accessed 26 April 2019.

57 Hartman, supra note 3, at 21-22.

58 As a side effect, scholars tend to analyse derogation practices based on case-law analysis. The scholarship in the area is therefore based on an incomplete source, namely ECtHR case law. For illustration, there is hardly any research on derogations from ECHR by Georgia in 2007 or Armenia in 2008 (for limited research on the topic see James Sweeney, The European Court of Human Rights in the Post-Cold War Era: Universality in Transition (2013) 189-190). This makes it particularly difficult to trace problems with derogations of very short duration, as the ones of Georgia or Armenia, both questionable for their validity.

59 See, e.g., Venice Commission, Turkey - Opinion on Emergency Decree Laws Nos 667-676 adopted following the failed coup of 15 July 2016, Opinion No 865/2016 (12 December 2016), Doc No CDL-AD(2016)037.

60 For earlier arguments on the role of the Secretary General see Christoph Schreuer, 'Derogation of Human Rights in Situations of Public Emergency: The Experience of the European Convention on Human Rights' (1982) 9 Yale Journal of International Law 131-132. 
(2018), notes three points under which the Secretary General could address derogations:

20.1 as depository of the Convention, provide advice to any State Party considering the possibility of derogating on whether derogation is necessary and, if so, how to limit strictly its scope;

20.2. open an inquiry under Article 52 of the Convention in relation to any State that derogates from the Convention;

20.3. on the basis of information provided in response to such an inquiry, engage in dialogue with the State concerned with a view to ensuring the compatibility of the state of emergency with Convention standards, whilst respecting the legal competence of the European Court of Human Rights. ${ }^{61}$

Accordingly, it seems that the Secretary General is meant to act as an expert and an active supervisory body over states derogating from the ECHR. The expert role would be exercised by way of providing advice on the aptness of derogations in the pre-derogation stage, or the scope of derogation measures in the post-derogation stage. The active supervisory role would be exercised by way of pressuring states to provide information and detailed reasons for derogations and engaging in continued dialogue with the states concerned about the nature, duration and adequacy of a derogation. This recommendation, however, raises further questions on the institutional competence of the Secretary General to exercise these functions.

\section{Secretary General as an Expert Body}

As regards the expert role, there is no clear support in Article 15 ECHR to suggest that states are obliged to seek advice prior to derogation. Rather, the practice of the ECtHR would indicate that the derogation notice can even be submitted post-festum, that is, after the emergency measures have been adopted. ${ }^{62}$ The role could prove useful, however, as states may have a genuine interest in expert advice by the $\mathrm{CoE}$ in certain situations. For example, a state or group of states might have a common interest in knowing about the use and aptness of derogations in the context of foreign military or counter-

${ }^{61}$ Resolution 2209 (2018), supra note 10.

62 In Lawless, the Court noted that the derogation notice submitted twelve days after the entry into force of the impugned measures was without delay. Lawless v Ireland (No 3), ECtHR, Application No 332/57, Judgment of 1 July 1961, para 47. 
terrorism operations. ${ }^{63}$ The UK, France, Turkey and other European states that are not infrequently engaged in foreign operations may benefit from a dialogue with the Secretary General on the legality and aptness of derogating from the ECHR extraterritorially. Also, a state encountering peculiar legal and political difficulties in times of war or emergencies may find it adequate to resort to the Secretary General for enquiries as an initial step to resolve these difficulties. Ukraine, for instance, has continuously struggled with the question how to qualify its military campaign to protect its territory from Russian aggression and pro-Russian military forces. ${ }^{64}$ In both situations, the Secretary General could provide information about best practices, namely the measures that have proved to be effective, but also about the counter-effects of derogations.

At the same time, the Secretary General may need to be very mindful of the way his advice can be used by governments which initially legitimately derogate from the ECHR but subsequently resort to disproportionate measures. Practice shows that the majority of derogation cases might be justified in the initial stage but become problematic later on. For instance, neither PACE nor any other institution has suggested that derogations could not be justified in the wake of Turkey's failed coup d'etat or the repeated terrorist attacks in or against France. In the light of this practice, there is a risk that states could use the dialogue platform in the pre-derogation stage to obtain an early 'validation' of derogation measures - and use it for the purpose of 'political consumption' - before such measures become inadequate or disproportionate.

\section{Secretary General as an Active Supervisory Body}

The PACE Resolution 2209 recommends that the Secretary General could open an inquiry into the derogation by any state and engage in a continued dialogue about the compatibility of the state of emergency proclamation and the attendant derogation with the Convention. The Secretary General could

63 For the intricate legal issues of extraterritorial derogations, see Marko Milanovic, 'Extraterritorial Derogations from Human Rights Treaties in Armed Conflicts' in Nehal Bhuta (ed), The Frontiers of Human Rights (2016) 55.

64 See Benedikt Harzl and Oleksii Plotnikov, 'Ukraine's Derogation From the European Convention on Human Rights' (2019) 22 ARIEL 29. See also 'Poroshenko: ATO over, Joint Forces Operation starting' UNIAN Information Agency (18 March 2018) <unian.info/war/10045583-poroshenko-ato-over-joint-forcesoperation-starting.html > accessed 26 April 2019. 
exercise this active supervisory role in derogation practices by invoking Article 52 ECHR ('Inquiries by the Secretary General'), which provides:

On receipt of a request from the Secretary General of the Council of Europe any High Contracting Party shall furnish an explanation of the manner in which its internal law ensures the effective implementation of any of the provisions of the Convention.

The language of Article 52 ECHR confirms that a state is under an obligation to provide the information requested by the Secretary General. 'The language used - "shall furnish an explanation" - is rather imperative" ${ }^{65}$ The Secretary General himself explained the mandatory nature of inquiries under Article 52 as follows:

The State has the obligation to provide truthful explanations. It appears clearly from the wording of Article 52 that this obligation is unconditional. The scope of the obligation is defined by Article 52 itself. The State must furnish the requested explanations about 'the manner in which its internal law ensures the effective implementation of any of the provisions of this Convention'. The State has an obligation of result to provide explanations about the effective implementation of the Convention in its internal law: the State cannot, therefore, confine itself to providing explanations of a formal nature. On the contrary, bearing in mind also the obligation to execute treaty obligations in good faith (Article 26 of the Vienna Convention on the Law of Treaties of 23 May 1969), a State has the obligation to furnish precise and adequate explanations which make it possible to verify whether the Convention is actually implemented in its internal law. This necessarily implies that the State must furnish information of a sufficiently detailed nature about the national law and the practice of the national authorities, in particular the judicial authorities, and about their conformity with the Convention as interpreted in the case-law of the European Court of Human Rights. ${ }^{66}$

Article 52 ECHR does not limit the scope of inquiries. Thus, they can be specific or general in character. Neither does Article 52 limit the Secretary General's competence to request information on a regular basis or on any

65 Schabas, supra note 49 , at 898.

${ }_{66}$ Council of Europe, Secretary General's report under Article 52 ECHR on the question of secret detention and transport of detainees suspected of terrorist acts, notably by or at the instigation of foreign agencies, SG/Inf (2006) 5, 28 February 2006, para 12. 
issue pertaining to the Convention. In this regard, the Secretary General has a wide discretionary power to supervise any type of derogation and engage in dialogue with states about any aspect of derogations, whether the derogation measure is of short or long duration. Such inquiries exert a certain degree of pressure on derogating states and ensure continuous international supervision. The Secretary General, however, must develop sufficient expertise and procedures to exercise his function properly and effectively. ${ }^{67}$

The PACE recommendations about the expert and supervisory role of the Secretary General are complementary and mutually reinforcing. The expert role at the pre-derogation stage would ensure that the Secretary General's task is first and foremost to help with advice in times of crisis. The supervisory role during derogations from the ECHR provides the continuation of a dialogue, but this time through a more demanding language. The comprehensive engagement at all stages of derogation allows the Secretary General to identify areas of concern in due time, raise early warning remarks with the state concerned and, when necessary, bring urgent requests to the Committee of Ministers and the PACE for political pressure on the derogating state.

While the active role by the Secretary General does of course not set aside or limit the wide discretionary power of states to derogate from the Convention, it ensures that any problematic features of derogations are monitored instantly through a 'new layer' of international supervision of derogation practices.

\section{Conclusions}

For a long time, scholars and institutions have argued that derogations may be justified only if they are temporary. This claim is not supported by the language of Article 15 or the Court's case-law. Furthermore, the assumption is based on an unfitting analogy, that is, it has misappropriated the notion of

67 PACE has recently asked the Committee of Ministers to 'examine State practice in relation to derogations from the [ECHR], in the light of the requirements of Article 15 and the case law of the European Court of Human Rights, the requirements of international law and the Assembly's findings and recommendations in Resolution 2209 (2018), with a view to identifying legal standards and good practice and, on that basis, adopt a recommendation to member States on the matter'. The Committee of Ministers should share such information with the Secretary General who is tasked to establish continued dialogue with derogating states. See Parliamentary Assembly of the Council of Europe, Recommendation 2125 (2018), 24 April 2018, para 2. 
temporariness under the state of emergency (as constitutional vernacular) to temporariness under derogation regimes (as an international law vernacular). As the two vernaculars have different genealogies and different purposes, the aspect of temporariness under constitutional law cannot be simply transposed to the derogation regime under the ECHR for the purpose of imposing a non-existent limit on the duration of derogations. Neither the wording nor the case-law of the ECtHR support such a transposition.

Against this background, it is suggested that a more rigid supervision of derogations can better address problems associated with their duration, among other issues. To that end, two 'policy recommendations' that find support in the existing provisions of the ECHR may be made: first, an enhanced judicial supervision of derogations and, second, an active non-judicial, political or diplomatic supervision of derogations by the Secretary General of the CoE. To be sure, this form of active judicial and non-judicial supervision of derogation cases cannot rewrite Article 15 ECHR to diminish the discretionary power of states to derogate from the Convention or to add a temporal limitation to derogations. However, the active involvement by the Court and the Secretary General can ensure that complex derogation regimes are monitored more effectively and reviewed more timely for their individual human rights abuses and systemic societal effects. 